\title{
Profitability of Prosumers According to Various Business Models-An Analysis in the Light of the COVID-19 Effect
}

\author{
Maciej Sołtysik $^{1}$, Mariusz Kozakiewicz ${ }^{2}$ and Jakub Jasiński ${ }^{3, *} \mathbb{D}$ \\ 1 Faculty of Electrical Engineering, Częstochowa University of Technology, Armii Krajowej St. 17, \\ 42-200 Czestochowa, Poland; maciej.soltysik@pcz.pl \\ 2 Collegium of Economic Analysis, Warsaw School of Economics, Madalińskiego 6/8 St., \\ 02-513 Warsaw, Poland; mariusz.kozakiewicz@sgh.waw.pl \\ 3 Institute of Rural and Agricultural Development, Polish Academy of Sciences, 72 Nowy Świat St., \\ 00-330 Warsaw, Poland \\ * Correspondence: jjasinski@irwirpan.waw.pl
}

Citation: Sołtysik, M.; Kozakiewicz,

M.; Jasiński, J. Profitability of

Prosumers According to Various Business Models-An Analysis in the Light of the COVID-19 Effect. Energies 2021, 14, 8488. https://doi.org/ $10.3390 /$ en14248488

Academic Editor: Behnam Zakeri

Received: 13 November 2021 Accepted: 15 December 2021 Published: 16 December 2021

Publisher's Note: MDPI stays neutral with regard to jurisdictional claims in published maps and institutional affiliations.

Copyright: (c) 2021 by the authors. Licensee MDPI, Basel, Switzerland. This article is an open access article distributed under the terms and conditions of the Creative Commons Attribution (CC BY) license (https:// creativecommons.org/licenses/by/ $4.0 /)$.

\begin{abstract}
The European Union has set itself ambitious emission-reduction targets-becoming carbon neutral by 2050. The member states' energy systems are increasingly switching to renewable and decentralized configurations, in line with the EU guidelines. This is accompanied by the support for "prosumers" - entities that both consume and generate renewable energy. In parallel, a number of prosumer support schemes are emerging as a result of the search for optimal development paths. At the same time, the COVID-19 pandemic has significantly affected the power market, causing huge anomalies mainly in demand and billing. The objective of the study was to assess the impact of the proposed changes in the prosumer schemes on the level of benefits prosumers obtained, including the performance of sensitivity analyses reflected in different levels and stability of electricity consumption resulting from extreme situations caused by the COVID-19 pandemic. Numerical computer simulations for five predefined prosumer support schemes were carried out in the R-project environment. The basic conclusion is that the prosumer benefits most from participating in the applicable discount mechanism, in which the unused energy is fed into a network storage, from which the prosumer can take $70 \%$ or $80 \%$ of the stored volume. The research also allows us to conclude that in Poland the COVID-19 pandemic has had a very significant impact on the level and profile of energy demand due to the introduction of restrictions on selected areas and economic sectors. The reduced demand is particularly visible in services $(-58 \%)$, tourism and sport $(-39 \%)$, and education $(-19 \%)$. The analysis is an important contribution to the search for an optimal model of prosumer market development in Europe.
\end{abstract}

Keywords: energy transitions; renewable energy; prosumers; COVID-19 and energy sector

\section{Introduction}

In December 2018, an amended Renewable Energy Directive (Directive (EU) 2018/2001) entered into force in the European Union as part of the "Clean Energy for all Europeans" package [1-4]. Its objective was to maintain the EU's position as a global leader in renewable energy sources (RES) and to meet its emission reduction liabilities under the Paris Agreement [5,6]. The Directive set a binding target according to which by 2030 at least $32 \%$ of the final energy consumed in the European Union should be obtained from renewable sources. One year later, in December 2019, the European Commission presented a Communication on the European Green Deal (COM(2019)0640) [7]. The document set out a detailed vision which assumed that the EU will become climate neutral by 2050, delivering clean, affordable and safe energy [8,9].

An increasing role in achieving ambitious reduction targets in the EU is attributable to distributed energy and prosumerism [10-12]. Prosumers are individuals, groups of citizens, households or farms that may act both individually and in organized forms, who are at 
the same time consumers and producers of energy generated in small installations in backyards or on residential and commercial buildings (e.g., mini wind turbines, photovoltaic panels). Prosumers may also be enterprises [13], institutions and local authorities [14-16]. Individual EU countries use various incentives, mainly of a financial [17] and billing nature [18-20], to develop the prosumer market. The share of the prosumer energy sector in total energy generation should always be adapted to the characteristics of the individual member states [21], i.e., the development and implementation of solutions affecting the the prosumer market should take into account:

- the specificities of the energy and transmission system in a given country [22-24],

- the structure of energy production and consumption [25-28].

In its opinion published in 2017, the European Economic and Social Committee (EESC) proposed that the framework rules for the prosumer energy sector should be developed at the EU level, while detailed regulations in this regard should remain the domain of each member state [14]. After three years, the EESC's proposals were reflected in the Community legislation [29] and currently the solutions introduced in the individual EU countries, although based on the same legal framework and guidelines of the Community institutions, differ considerably from each other. It is therefore necessary to seek the most effective solutions supporting the development of the prosumer and RES energy sector and to popularize models that will help determine the optimal conditions for the development of this market in a given supply and demand reality, taking account of the specificities of a particular country or region [30].

In 2021, several proposals for solutions and bills that would change the prosumer billing model in the near future were developed by expert groups and decision-makers (representatives of the government and parliament) in Poland. Although individual proposals and their assumptions differ from each other, each assumes abandoning the "net metering" billing system, which has been functioning in Poland for years, and moving towards "marketization" of the existing model by giving prosumers the ability to resell surplus energy not consumed at the moment of its generation. Currently, the prosumer settles the amount of electricity fed into the network in relation to the amount taken from it-the amount of energy that can be taken from the network at no cost depends on the prosumer's total installed power:

(1) power not exceeding $10 \mathrm{~kW}$-feeding into the network (production) in relation to off-take (consumption) at a 1:0.8 ratio;

(2) power exceeding $10 \mathrm{~kW}$ and not exceeding $50 \mathrm{~kW}$-feeding into the network (production) in relation to off-take (consumption) at a 1:0.7 ratio [31];

(3) power not exceeding $1 \mathrm{MW}$ for power cooperatives-feeding into the network (production) in relation to off-take (consumption) at a 1:0.6 ratio [32].

The provisions in force allow for a model in which, through government programs or local authorities, for example, a photovoltaic source is installed which generates more electricity than the prosumer can consume. The surplus is fed into the network where it is "stored" [33]. Then, in periods when the production from renewable sources (mainly photovoltaic sources) is lower, part of this energy is recovered by the prosumer [32]. This model is beneficial for consumers, implying a high demand interest in installations, and thus in entrepreneurs selling and assembling photovoltaic installations. However, the discount mechanism is a heavy burden for trading companies (energy sellers) and distribution system operators (energy distribution infrastructure owners), which has given rise to several different proposals for changes in the prosumer billing and support system. In view of the above, Poland now seems to be a very good field for the analysis of prosumerism development models. Using examples of solutions contained in actual bills created as part of the EU legal discipline dedicated to the development of green energy, the authors attempted to analyze several prosumer market development models and assumptions that will be the most beneficial for a micro-installation owner. This is the paper's contribution 
to scientific literature, which can furthermore contribute to an effective and sustainable development of the prosumer market both in Poland and in other EU countries.

At the same time, it should be taken into account that since 2020, all analyses and predictions relating to the energy sector worldwide have been complicated by the COVID19 pandemic, which has definitely changed and distorted the structure of energy demand. The first wave of COVID reached Poland in March 2020, which resulted in lockdown as of 16 March 2020. Subsequent waves occurred in autumn-winter 2020/2021 and spring 2021. The result of the government restrictions-strengthened during periods of increased incidence of the disease-was a limitation of social and economic life, unevenly affecting various sectors of the economy, which had an impact on changes in the demand for electricity. The analyses presented in the paper take account of the "COVID-19 effect" in the power market (energy demand) and focus on two objectives:

(1) Verification of which of the models of billing and support for the development of the prosumer market proposed in Poland would be the most beneficial to entities consuming and producing energy (prosumers).

(2) Assessment of how the COVID-19 pandemic could affect individual types of prosumers depending on the billing model applied.

The paper is structured as follows. The second section provides a detailed description of the proposed prosumer billing and support mechanisms for Poland. This section also describes the research sample (output data and its selection), presents the assumptions made by the authors and the methodology used in the research process. This is followed by the research findings for the period from March 2018 to March 2021, which are discussed and provided with expert commentary, and finally conclusions are drawn and presented so that the overall analysis and research work can be concluded.

\section{Materials and Methods}

\subsection{Research Scenarios—Billing and Support Models}

In order to carry out a simulation and examine the potential benefits for prosumers, it was necessary to prepare several simulation variants reflecting the modification scenarios for the prosumer billing and support mechanism analyzed and considered by expert groups and decision-makers in Poland.

The various tools and conditions regarding billing systems and prosumer support make it possible to generate several dozen different scenarios. It would not be possible to present such a number of variants (scenarios) in a scientific article, the more so as it will never be a closed catalog of support schemes. The authors decided to focus on scenarios that have actually appeared in the public debate in Poland as mutual counterproposals, and have also been analyzed by legal experts as compliant with EU law. The scenarios analyzed are based on the "marketization" of the existing discount model, giving prosumers an opportunity to resell surplus energy not subject to consumption at the time of its generation. A synthesis of the scenarios is presented in Table 1, and the detailed characteristics are as follows:

- CASE_0_A baseline scenario mapping the mechanism currently functioning in Polish law. This assumes the billing of the prosumer based on the "discount model". In this model, the energy produced by the prosumer and unused at a given moment is fed into the distribution network acting as a deposit, from which the prosumer can take $70 \%$ or $80 \%$ of the accumulated volume. This level depends on the power of the source and amounts to $80 \%$ for installed power up to $10 \mathrm{~kW}$ and $70 \%$ for power ranging from 10 to $50 \mathrm{~kW}$. The off-take of energy from the deposit may be made at any time within the annual billing period when the prosumer's production source does not cover the demand. The off-take of energy from the deposit is not subject to any fees, and any costs to the distribution network operator and the obligated seller (the entity that has to buy and settle the energy from RES) [34] are covered in the discount volume. If the amount deposited is not sufficient to cover the prosumer's energy demand, the missing part is purchased in accordance with the tariff or price 
list of the seller with whom the prosumer has signed a comprehensive agreement and in accordance with the tariff of the distribution network operator to whose network the prosumer is connected.

- $\quad$ CASE_1-A scenario in which the discount does not apply. Electricity consumption at times coinciding with production under self-consumption is not subject to any fees. Surplus energy is resold to the obligated seller at the Competitive Market Price (PL: CRK), which is calculated and published quarterly by the President of the Energy Regulatory Office [35]. Electricity taken from the distribution network is subject to fees in accordance with the tariff or price list of the seller with whom the prosumer has signed a comprehensive agreement and in accordance with the tariff of the distribution network operator to whose network the prosumer is connected.

- CASE_2-A scenario similar to CASE_0. Electricity consumption at times coinciding with production under self-consumption is not subject to any fees. Surplus energy is fed into the distribution network under a deposit from which the full $100 \%$ can be taken at any time within the billing period. The energy taken from the deposit is subject only to distribution fees in accordance with the tariff of the distribution network operator in the area where the prosumer is connected. If the amount deposited is not sufficient to cover the prosumer's energy demand, the missing part is purchased in accordance with the tariff or price list of the seller with whom the prosumer has signed a comprehensive agreement and in accordance with the tariff of the distribution network operator to whose network the prosumer is connected.

- CASE_3-A scenario aimed at marketizing the resale of surplus energy production by the prosumer. In this model, electricity self-consumption as in the previous scenarios is not subject to any fees. Surplus electricity is resold by the prosumer in the daily and hourly market at "fixing prices". There is no discount mechanism or network deposit in this model. By reselling the surplus, the prosumer earns proceeds from the sale of energy. In situations of deficit, the energy demand is covered by the purchase of energy from the seller with whom the prosumer has signed a comprehensive agreement. This purchase is made at the applicable tariff or price list price. The energy purchased in this way is also subject to a full distribution fee consistent with the tariff of the local distribution network operator.

- CASE_4-A scenario proposed and promoted by energy trading companies and aimed at marketizing the resale of surplus energy production by the prosumer. The scenario's assumptions are identical to those of CASE_3, the difference being the inclusion of a different set of prices in the sale process. The surplus is resold at the Market Energy Price (PL: RCE) [36] calculated and published by the Transmission System Operator. The RCE is equivalent to the monthly average of the hourly prices weighted by the volume of surplus energy sold by the prosumer. This price is therefore fixed within each month of the billing period, which facilitates the handling of settlements in billing systems.

\subsection{Assumptions and Sample Selection}

The analyses presented by the authors focus both on verifying which of the models of billing and support for development of the prosumer market proposed in Poland will be the most beneficial to entities producing and consuming energy (prosumers), as well as on assessing how the COVID-19 pandemic could affect individual types of prosumers depending on the potential billing model. In order to be able to make relevant analyses and comparisons between the individual proposed variants of billing of and support for prosumers, the authors decided to introduce the following assumptions in the research: 
Table 1. Synthetic presentation of individual variants (scenarios) for analysis.

\begin{tabular}{|c|c|c|c|c|}
\hline & Discount & $\begin{array}{c}\text { Network } \\
\text { Deposit }\end{array}$ & Resale of Energy & Purchase of Energy \\
\hline CASE_0 & $\begin{array}{ll} & 1 / 0.7 \text { for } \\
10-50 \mathrm{~kW} \\
\text { sources } \\
1 / 0.8 \text { for } \\
\text { sources of } \\
\text { up to } \\
10 \mathrm{~kW}\end{array}$ & Yes & No & $\begin{array}{ll}\text { - } & \text { Energy: tariff/price list } \\
\text { - } & \text { Distribution: tariff } \\
\text { Applies to the volume } \\
\text { outside the } \\
\text { network deposit }\end{array}$ \\
\hline CASE_1 & No & No & $\begin{array}{l}\text { At the CRK } \\
\text { determined } \\
\text { quarterly by the } \\
\text { President of the } \\
\text { Energy Regulatory } \\
\text { Office (URE) }\end{array}$ & $\begin{array}{ll}\text { - } & \text { Energy: tariff/price list } \\
\text { - } & \text { Distribution: tariff }\end{array}$ \\
\hline CASE_2 & $1 / 1$ & Yes & No & $\begin{array}{ll}\text { - } & \text { Energy: no fees } \\
\text { - } & \text { Distribution: tariff } \\
\text { Applies to the volume } \\
\text { from the } \\
\text { network deposit } \\
\text { - } \quad \text { Energy: tariff/price list } \\
\text { - } \quad \text { Apstribution: tariff } \\
\text { outside the } \\
\text { network deposit }\end{array}$ \\
\hline CASE_3 & No & No & $\begin{array}{l}\text { At fixing prices from } \\
\text { the energy exchange }\end{array}$ & $\begin{array}{ll}\text { - } & \text { Energy: tariff/price list } \\
\text { - } & \text { Distribution: tariff }\end{array}$ \\
\hline CASE_4 & No & No & $\begin{array}{l}\text { At the RCE } \\
\text { (monthly average of } \\
\text { the hourly prices } \\
\text { weighted by the } \\
\text { volume of resold } \\
\text { surplus energy) }\end{array}$ & $\begin{array}{ll}\text { - } & \text { Energy: tariff/price list } \\
\text { - } & \text { Distribution: tariff }\end{array}$ \\
\hline
\end{tabular}

1. Optimization assumption: minimization of off-take from the network and maximization of the use of the network deposit (energy fed into the network and available for off-take by the prosumer). It is necessary to stress that the energy fed into the network must be used (taken) by the prosumer within one year of its introduction.

2. Assumption regarding the period analyzed: The first lockdown in Poland took place in March 2020. The availability of actual electricity consumption metering data in the period from March 2018 to March 2021 made it possible to move the "analysis window" to the period from March to March. This assumption was made for the purpose of easier interpretation of the results of the analyses.

3. Assumptions regarding prices-depending on the scenario analyzed, the following price and cost indicators were considered:

a. RCE (Market Energy Price) [36] - the price at which the prosumer sells surplus energy under the CASE_4 scenario.

b. $\quad$ FIXING_I price [37] - the price at which the prosumer sells surplus energy under the CASE_3 scenario.

c. CRK (Competitive Market Price) [38]—-the price at which the prosumer sells surplus energy under CASE_1.

d. distribution cost [39] - the components of distribution rates valid for a given year (2018, 2019 and 2020) were taken into account: (i) variable component of the network rate, (ii) quality rate, (iii) cogeneration fee charged to the consumer 
when purchasing electricity from the network. For the analyses, the rates specific to the operator to the network of which the analyzed consumers are connected were used. Due to the NDA with the operator, its identity remains undisclosed. The distribution cost was used in CASE_0 and 2 scenarios to settle the purchase of energy from outside the network deposit and in CASE_1, 3 and 4 scenarios to settle the purchase of energy from the network.

e. purchase cost [39] - the rates of electricity selling prices incurred by the analyzed customers, applicable to a given year $(2018,2019$ and 2020), were taken into account. The analyses were based on rates specific to the sales company with which the given consumer had signed a comprehensive electricity sales agreement. Due to the NDA concluded with the sales company, its identity remains undisclosed. The price was used in CASE_0 and 2 scenarios to settle the purchase of energy from outside the network deposit and for CASE_1, 3 and 4 scenarios to settle the purchase of energy from the network.

4. Assumption regarding the sample-consumption input data: The consumers were selected for analyses taking into account the following criteria:

a. location in rural and urban-rural areas within various administrative districts and within a single voivodeship (the area administered by a voivode, commonly known as the region-Poland consists of sixteen voivodeships [40]), in order to address both location diversity and the impact of implementing COVID-19 pandemic restriction zones.

b. availability of actual daily-hourly electricity consumption data for each consumer.

c. reflection of the varied nature of the economic activity pursued. The consumers were selected based on their affiliation with one of the following categories: (i) trade and sales, (ii) tourism and sport, (iii) services, (iv) education, (v) food production, (VI) household, (VII) others. This diversity made it possible to assess the mapping of the impact of the COVID-19 pandemic at the level of energy demand for individual sectors and to describe and assess the benefits/losses resulting from implementing one of the four scenarios of prosumer support considered under normal conditions before the pandemic and under stress-test conditions during the COVID-19 pandemic.

d. technical and location conditions making it possible to construct a photovoltaic power generation source.

5. Assumption concerning the sample-generation input data:

a. the selection of the power of the photovoltaic source was based on a numerical algorithm described in the further part of the paper aimed at achieving the consumer's energy self-sufficiency.

b. the analyses for each year assume a zero initial stock of network storage. For this reason, there is increased power consumption from the network in March in every year analyzed.

c. only PV sources for building self-sufficiency of prosumers were considered [41,42].

Based on the above criteria, a sample was selected from the population whose selected statistics and allocation to different economic sectors are presented in Table 2. 
Table 2. Summary of statistics for prosumers included in the sample from the population analyzed.

\begin{tabular}{|c|c|c|c|c|c|c|c|}
\hline & & \multicolumn{5}{|c|}{$\begin{array}{l}\text { Electricity Consumption } \\
\text { (Description for the Analyzed Period } 1 \text { March } \\
\text { 2018-28 February 2019) }\end{array}$} & \multirow[t]{2}{*}{ PV Power } \\
\hline & & Min. & Avr & Median & Max. & Total & \\
\hline & & \multicolumn{4}{|c|}{ kWh } & MWh/Year & $\mathbf{k W}$ \\
\hline \multirow{4}{*}{ Trade and sales } & Local market & 0 & 1.526 & 1.322 & 3.121 & $13,365.847$ & 49.0 \\
\hline & Supermarket & 0 & 0.745 & 0.746 & 1.342 & 6521.986 & 24.5 \\
\hline & DIY store & 0 & 1.517 & 1.929 & 5.595 & $13,291.612$ & 49.6 \\
\hline & Grocery store & 0 & 1.343 & 1.412 & 3.176 & $11,767.56$ & 43.5 \\
\hline \multirow{2}{*}{ Tourism and sport } & Agritourism guesthouse & 0 & 1.185 & 1.218 & 2.008 & $10,382.808$ & 39.0 \\
\hline & Swimming pool & 0 & 1.379 & 1.408 & 3.19 & $12,077.8$ & 46.5 \\
\hline \multirow{3}{*}{ Services } & Restaurant & 0 & 1.483 & 1.666 & 2.987 & $12,987.894$ & 49.0 \\
\hline & Coffee bar & 0 & 0.888 & 0.752 & 2.501 & 7781.909 & 28.5 \\
\hline & Hairdressing salon & 0 & 0.266 & 0.02 & 2.643 & 2329.799 & 8.0 \\
\hline \multirow{2}{*}{ Education } & School & 0 & 1.511 & 0.892 & 7.174 & $13,233.069$ & 49.0 \\
\hline & Kindergarten & 0 & 1.505 & 0.912 & 11.339 & $13,184.113$ & 49.0 \\
\hline \multirow{4}{*}{ Food production } & Dairy cooperative & 0 & 1.383 & 0.66 & 4.923 & $12,111.603$ & 43.8 \\
\hline & Bakery & 0 & 1.459 & 1.5 & 2.561 & $12,783.102$ & 49.0 \\
\hline & Chicken farm & 0 & 1.43 & 1.083 & 6.266 & $12,523.479$ & 45.0 \\
\hline & Agricultural enterprise & 0 & 1.406 & 0.1 & 31.849 & $12,316.534$ & 49.0 \\
\hline \multirow{2}{*}{ Household } & Household (G11) & 0 & 0.202 & 0.147 & 1.808 & 1773.785 & 5.0 \\
\hline & Household (G12) & 0 & 0.275 & 0.298 & 1.107 & 2406.909 & 9.0 \\
\hline \multirow{4}{*}{ Others } & Petrol station & 0 & 1.172 & 1.156 & 3.257 & $10,264.825$ & 40 \\
\hline & Medical clinic & 0 & 1.177 & 0.886 & 3.104 & $10,309.523$ & 38.0 \\
\hline & $\begin{array}{l}\text { Church } \\
\text { (without presbytery) }\end{array}$ & 0 & 1.462 & 1.072 & 9.095 & $12,810.444$ & 49.0 \\
\hline & Presbytery & 0 & 0.192 & 0.146 & 2.512 & 1680.121 & 5.0 \\
\hline
\end{tabular}

\subsection{Optimization Model}

The time series of daily and hourly electricity consumption by individual consumers became the basis for selecting the optimum power of the photovoltaic source, calculated on the basis of numerical simulation results. The selection of power and completed simulations were carried out using the consumption time series as well as actual generation profiles of photovoltaic reference sources. On their basis, the coefficients of matching the production to the preset consumption profile were selected so as to obtain energy self-sufficiency at the hourly level.

The training data used in the simulation process originated from the period 1 March 2018-28 February 2019, and were replicated for three years so as to obtain $3 \times 365 \times 24$ input data vectors. These training data were fed into the simulation procedures. Numerical simulations were carried out in the R-project environment [43], which is commonly used for data analysis $[44,45]$. Below is a simplified code snippet in the language that was used to generate simulation results. All simplifications were aimed at improving the clarity of the presentation. The code developed in the R-Project language has been implemented to determine the optimal size of photovoltaic sources. 
1. FromVirtualStorage $<$ - function (tmpDemand,VirtualStorage,h)\{

tmpRecive $<-0$

idx $<-\max (1, \mathrm{~h}-365 \times 24)$

While (tmpReceive $<=$ tmpDemand \& idx $<$ h) \{

if (VirtualStorage[id $x>0])\{$

tmpReceive $<-$ tmpReceive + VirtualStorage[idx]

VirtualStorage[idx] $<-0$

\}

id $x<-i d x+1$

\}

if $($ tmpReceive $>$ tmpDemand $)\{$

VirtualStorage[idx-1] <- (tmpReceive-tmpDemand $)$

tmpReceive $<-$ tmpDemand

\}

return(

list $($ Receive $=$ tmpReceive,

VirtualStorage $=$ VirtualStorage)

)

\}

retList <- list()

for(Multiplier in seq $(1: 50,000))\{$

Production <- ProductionProfile*Multiplier

VirtualStorage $<-$ rep $(0$, length(hours)

Send $<-$ rep $(0$, length(hours))

Receive <- rep(0,length(hours))

Buy $<-$ rep(0,length(hours))

Demand <- DemandProfile

for(h in hours $)\{$

if $(h>24 * 365)$

VirtualStorage $\left[1:\left(h-365^{*} 24\right)\right]<-0$

if(Demand $[\mathrm{h}]<=$ Production $[\mathrm{h}])\{$

Send[h] <- (Production[h]-Demand[h])

VirtualStorage[h] <- ifelse(Multiplier $>10,0,7,0,8)^{*}($ Production[h]-Demand[h])

\}else\{

ret $<-$ FromVirtualStorage $(($ Demand[h]-Production[h]), VirtualStorage, $h)$

Receive $[\mathrm{h}]<-$ ret\$Receive

VirtualStorage $<-$ ret\$VirtualStorage

Buy $[\mathrm{h}]<-\max (0,(($ Demand$[\mathrm{h}]-$ Production$[\mathrm{h}])$-ret\$Receive[h] $))$

\}

\}

retList[[Multiplier]] <- list (

Production $=$ Production,

58. Demand $=$ Demand,

59. VirtualStorage $=$ VirtualStorage, 


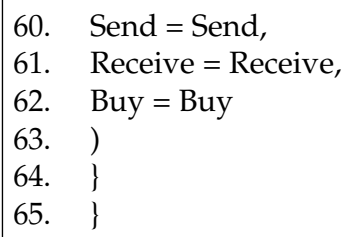

The main simulation loop is shown in lines 27-67. The loop control variable is the Multiplier which runs through the set from 1 to 50,000 . This variable is used to scale the production volume from a single PV source in $\mathrm{kW}$; ProductionProfile vector-line 29. The subsequent lines 30-34 are responsible for initializing the remaining input data of the simulation step for the determined Multiplier value.

Simulation takes place on hourly data. In lines 36-65, there is a loop statement where the control variable is hour (h), i.e., a set of all hours of the data horizon. In line 38, a condition is implemented which corresponds to the loss of energy not collected after the end of the billing period (one year, i.e., $365 \times 24 \mathrm{~h}$ ). In each hour of the horizon, two situations are possible-either energy demand is lower or equal to production (line 41), or demand is higher than production. If demand is not higher than production (lines 43-44), self-consumption takes place and the surplus energy is sent to a virtual energy storage, which will contain the energy appropriately reduced by the discount. If the demand in hour $\mathrm{h}$ is higher than production (lines 48-51), the energy is taken from the virtual storage and any missing energy is purchased. In line 48 , reference is made to the auxiliary FromVirtualStorage function whose implementation is found in lines 1-24. As part of this function, VirtualStorage is emptied in the sequence from the earliest energy portions sent to the latest (up to hour h) - this is implemented in lines 6-12. Then, if the relevant energy sent to the storage is higher than the demand in hour $h$, the surplus is overwritten in the last hour where the energy was taken-lines 14-17. The PV source size selection algorithm described above is illustrated in Scheme 1.

As a result of the simulation, the minimum Multiplier value was determined for which no energy was purchased from the network in the hours of the second and third data yearthe sum of the Buy vector in these hours was equal to 0. Finally, the value determined in this way (Multiplier reduced by $1 \mathrm{~kW}$ ) was adopted as the size of the source. This is equivalent to the highest power of the source, at which it is still necessary to purchase energy one year after its installation.

The above code (method) was used for simulation to determine the optimum size of photovoltaic sources (case 0). An identical code, after minor modifications, was used to generate data from the test periods 1 March 2019-29 February 2020 and 1 March 202028 February 2021. The modifications consisted in changing line 44 and determining the amount of the discount and in zeroing the volume sent to the virtual storage in the case of reselling the entire surplus energy.

One of the simulation results is visualized in Figure 1. The upper part of the graph shows the use of the virtual storage for case 0 . In order to improve the presentation, threefold training and test periods are collated there. The lower part of the chart shows the time series of purchases of energy from the seller and delivery through the distributor's network. The corresponding charts are time-synchronized. The training data from the period of 1 March 2018-28 February 2019 are marked in red, the training data based on the period of 1 March 2019-29 February 2020 are marked in green, and the test data based on the data from the period of 1 March 2020-28 February 2021 are marked in blue. In the case of this consumer, we can observe a slight oversizing as regards the size of the source-the level of use of the virtual storage shows a slight upward trend. At the end of each billing period (broken red line), a slight increase in the level of use of the storage year by year is visible. It can also be noted that for this test period, after the first year, there was no need to purchase electricity. In the case of test data based on the period of 1 March 2020-28 February 2021, a large oversizing as regards the source is visible. A significant 
volume of energy is being deposited, which is lost after the billing period expires (the blue curve is flattened in the middle of the billing period). This is caused by a significant decrease in the demand in the period of 1 March 2020-28 February 2021.

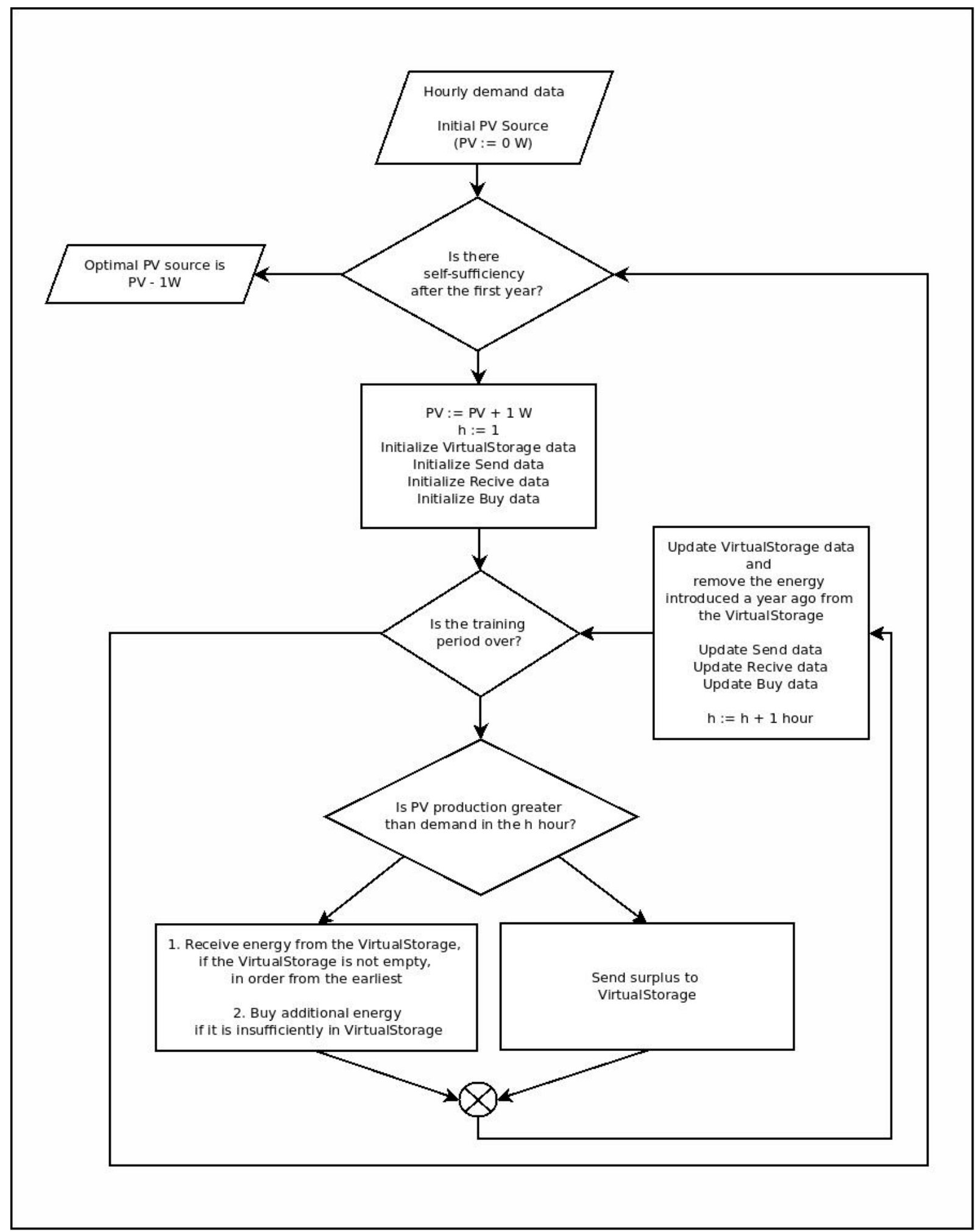

Scheme 1. Visualization of the method of PV source size selection. 


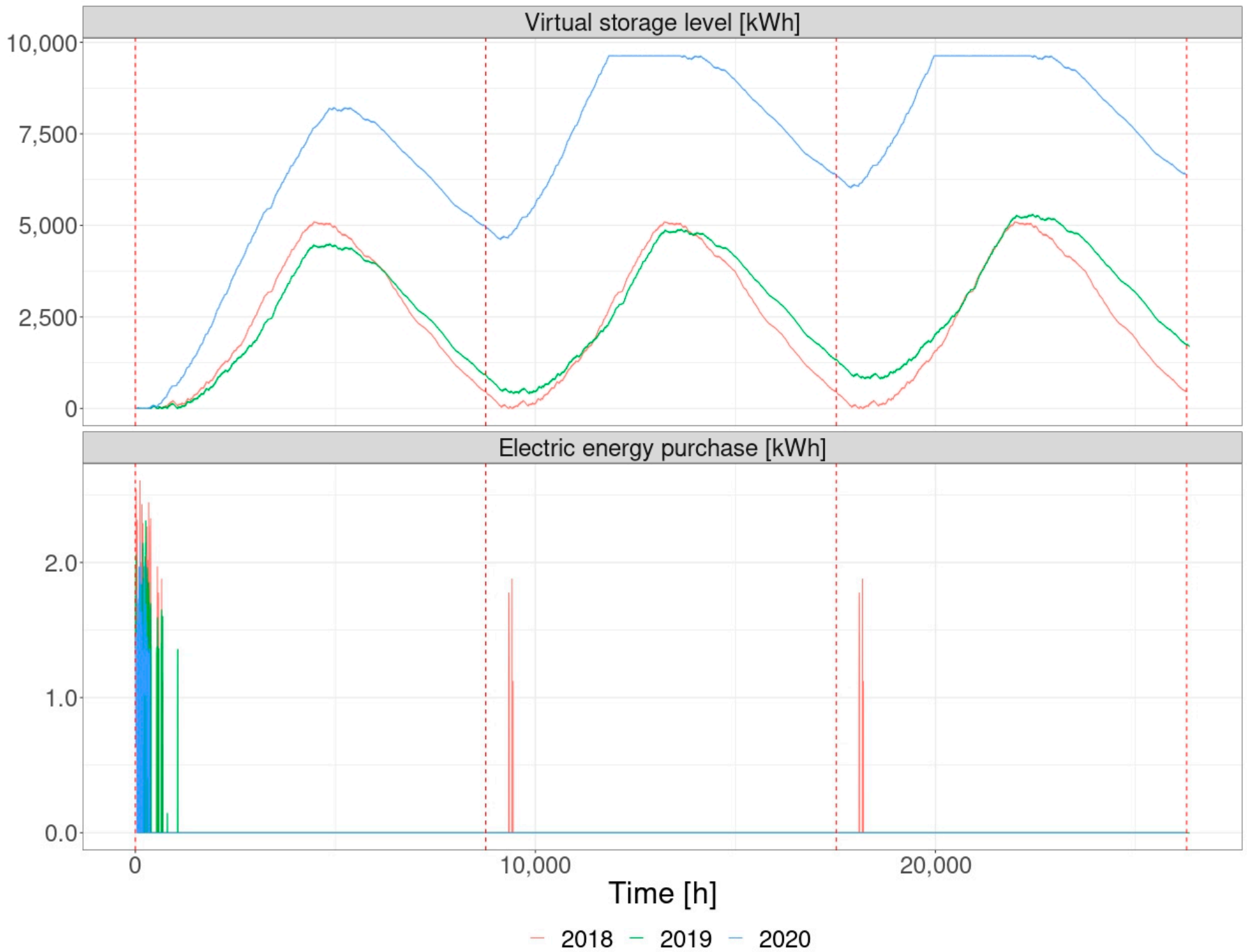

Figure 1. Visualization of the virtual storage fill level and energy purchase time series based on the Swimming Pool example, broken down by training period and test periods.

\section{Results and Discussion}

The results obtained during the studies are of dual nature. They concern both the assessment of the impact of the proposed and considered legislative changes on the benefits achieved by the prosumer, as well as the result of a specific sensitivity analysis and assessment of how extreme situations (COVID-19 effect) affect the behavior of consumers and how they translate into economic effects achieved by prosumers.

- The COVID-19 pandemic had a very clear impact on the decrease in the energy demand. Different dynamics of change were recorded depending on the category and type of consumer presented in Table 2. The demand in the pandemic period, i.e., March 2020-March 2021, in relation to the average demand for the period of March 2018-March 2020, decreased for the following types of business activities: (i) Trade and sales-15\%, (ii) Tourism and sport-39\%, (iii) Services-58\%, (iv) Education-19\%, (v) Food production - 6\%, (VI) Others-2\%. The only group that recorded an increase in the energy demand was Household- $5 \%$. The impact of COVID, visible at the level of individual recipients and branches of the economy, is a global phenomenon [46]. On a national scale, it manifests both in the context of the decline in energy demand [47] and the price implications for the wholesale electricity market $[48,49]$.

- The in-depth analysis of changes in the electricity consumption structure presented in Figure 2 indicates the existence of large disparities depending on the type of 
economic activity pursued. The decrease in the consumption was directly affected by the temporary closure of some industries. The highest decreases in demand were recorded for the service sector, including $62 \%$ for restaurants, $58 \%$ for coffee shops and $43 \%$ for hairdressing salons. The lockdown imposed on the tourist and sports sector resulted in energy consumption reduced by $43 \%$ for swimming pools and by $34 \%$ for agritourism guesthouses. The third most affected group of consumers belongs to the education sector, where schools and kindergartens saw a decrease in energy consumption of $30 \%$ and $7 \%$, respectively. An increase in consumption was also observed during the pandemic, in particular in households, up by $9 \%$, as well as in churches by $11 \%$ and small supermarkets by $4 \%$.

- In addition, the analysis of the energy demand of individual consumers indicates the natural volatility of electricity consumption as illustrated in Figure 3. Increases or decreases in consumption from March 2018 to March 2020 ranged from -12\% (decrease for households consuming energy based on a single zone tariff) to $+11 \%$ (increase for churches-religious buildings). The results of the dynamics of consumption from March 2020 to March 2021 compared to March 2018 to March 2019 are also interesting. The largest decrease, by $62 \%$ was for restaurants; its profile is presented in Figure 4 . The highest increase in consumption, by as much as $17 \%$, was for church buildings. This increase can be explained by a rise in the number of services in order to allow worshippers to attend mass and to meet the government's attendance quotas.

- When affecting the level of electricity demand, the COVID-19 pandemic also resulted in the impossibility of fully using the energy generated from prosumers' sources, which is illustrated in Figure 5. For March 2020-March 2018 compared to March 2019-March 2018, there is a stabilization of energy exchange with the network. The differences result from the natural volatility and nature of energy consumption in individual sectors of the economy.

However, significant changes are visible when comparing the period from March 2020 to March 2021 and March 2019 to March 2020. Then, the vast majority of prosumers note the intensified return of unused energy to the network. The highest rate of increase in returning electricity to the network is visible for hairdressing salons (34\%), coffee shops $(29 \%)$, restaurants $(24 \%)$, swimming pools $(20 \%)$ and agritourism farms $(14 \%)$.

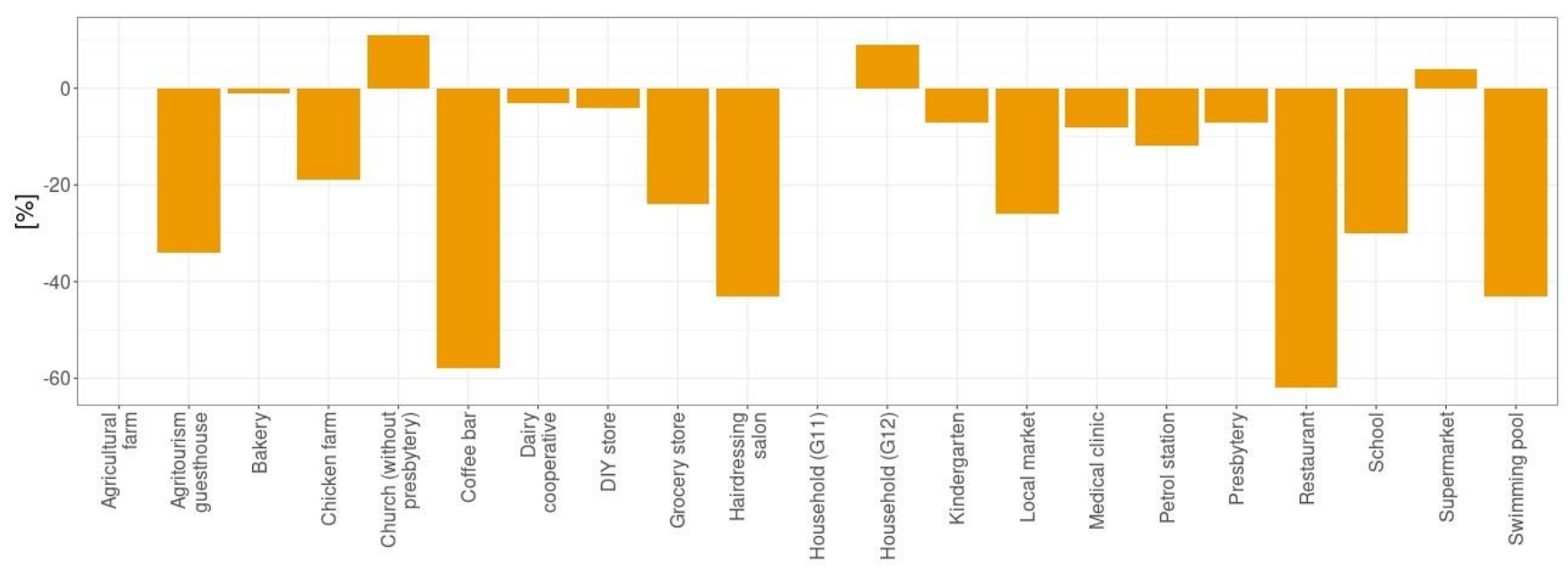

Figure 2. Change in electricity consumption from March 2020 to March 2021 in relation to average consumption from March 2018 to March 2020. 


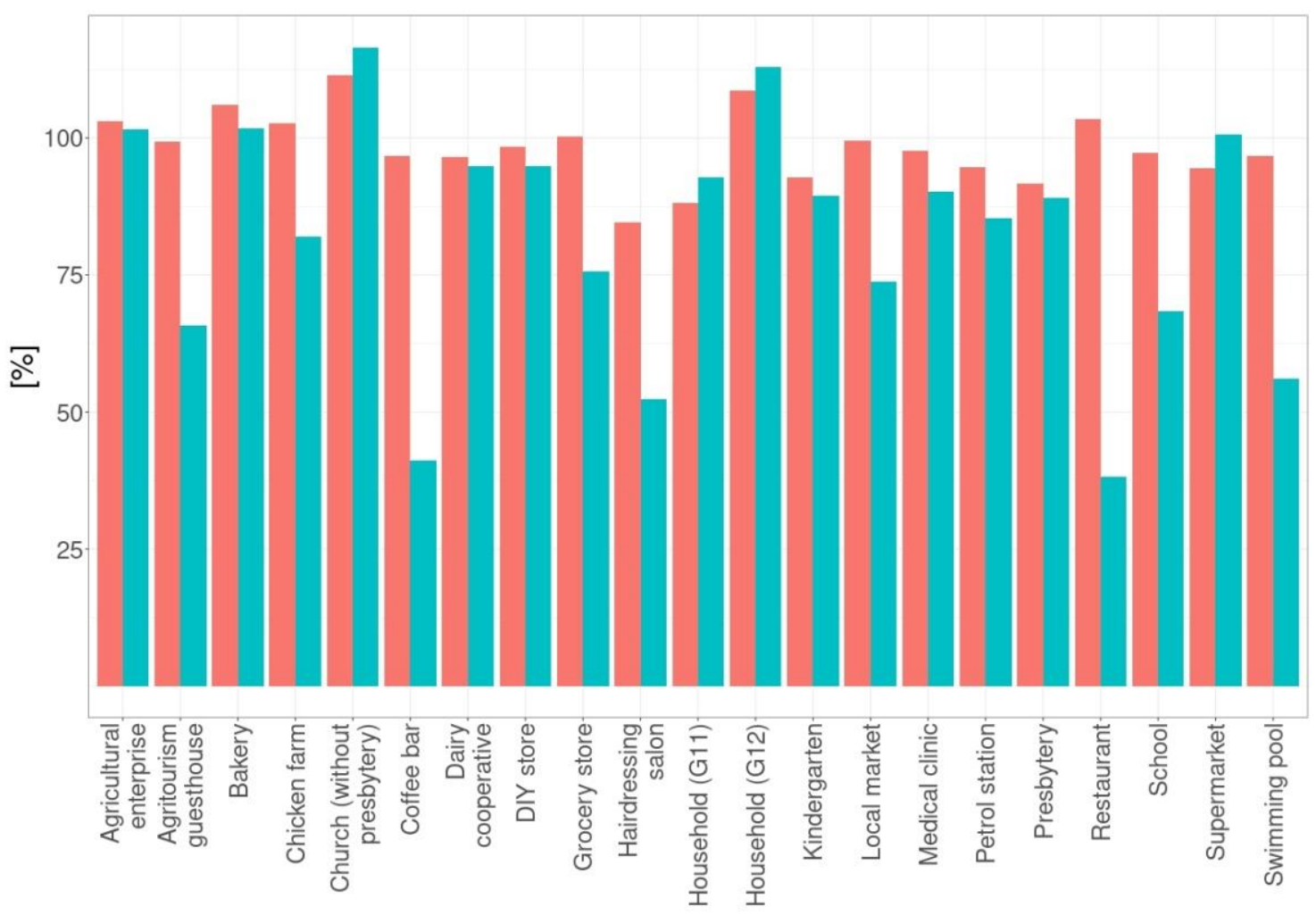

2019 relative to 20182020 relative to 2018

Figure 3. Relative demand for electricity broken down by types of activity.

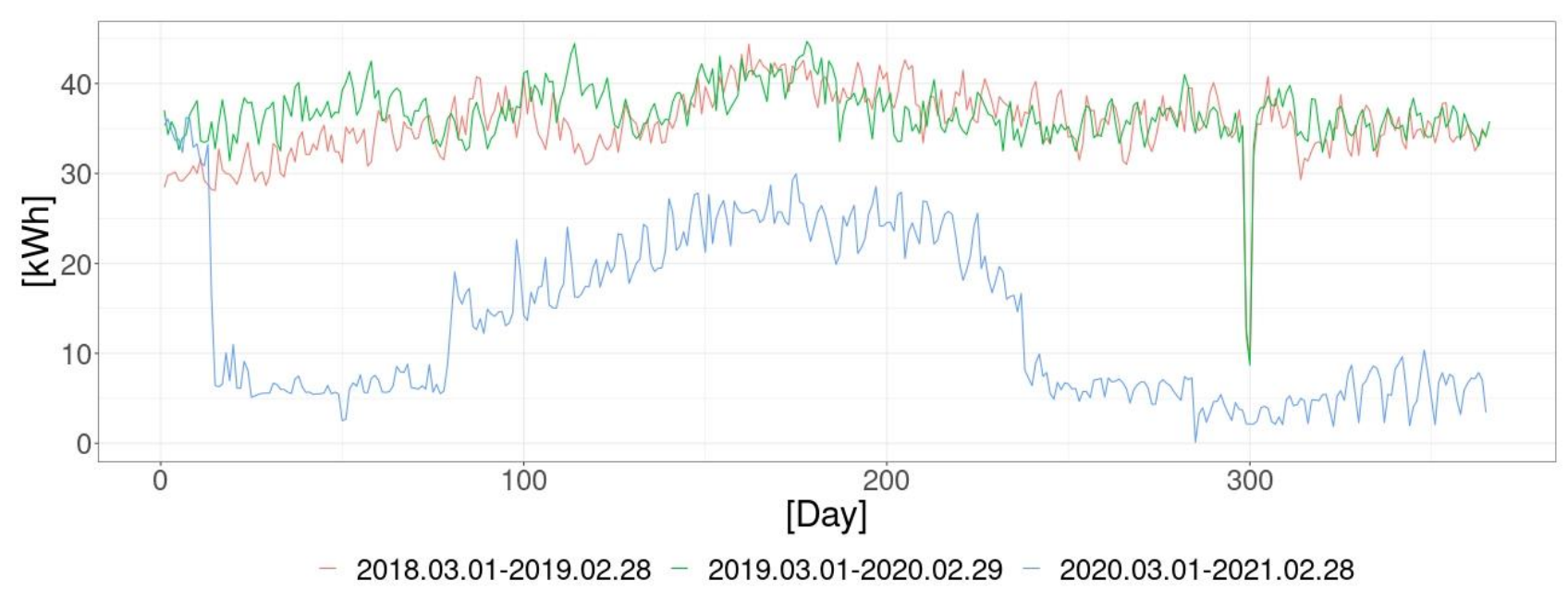

Figure 4. Daily demand for electricity in restaurants in individual analysis periods.

- Simulation of the selection of the generating source to energy self-sufficiency of consumers with a set and actual electricity consumption profile made it possible to map their actual behavior seen both from the technical and economic perspective. An energy consumer with a generating source functions as a prosumer, returning the surplus energy to the network storage (virtual storage) [33] or reselling it to the market under a specific market participation scheme. In each of the scenarios analyzed, there is a bidirectional exchange of electricity with the network. The surplus is either sent to the network storage or resold to the market, and shortages are taken from the network storage at no cost or purchased from the market. The scale of this exchange depends on 
the energy consumption within the annual billing period and on the correct selection of the generating source's power. In the cases analyzed, the source's power was selected so as to minimize the purchase of energy from outside the network storage for the discount model (case_0). Figure 6 shows the consumption/purchase of electricity from the distribution network. It is worth noting that despite the pandemic and reduction in the electricity consumption, some prosumers are experiencing an increase in the purchase of energy from the network, which is a consequence of consumption in low generation periods.

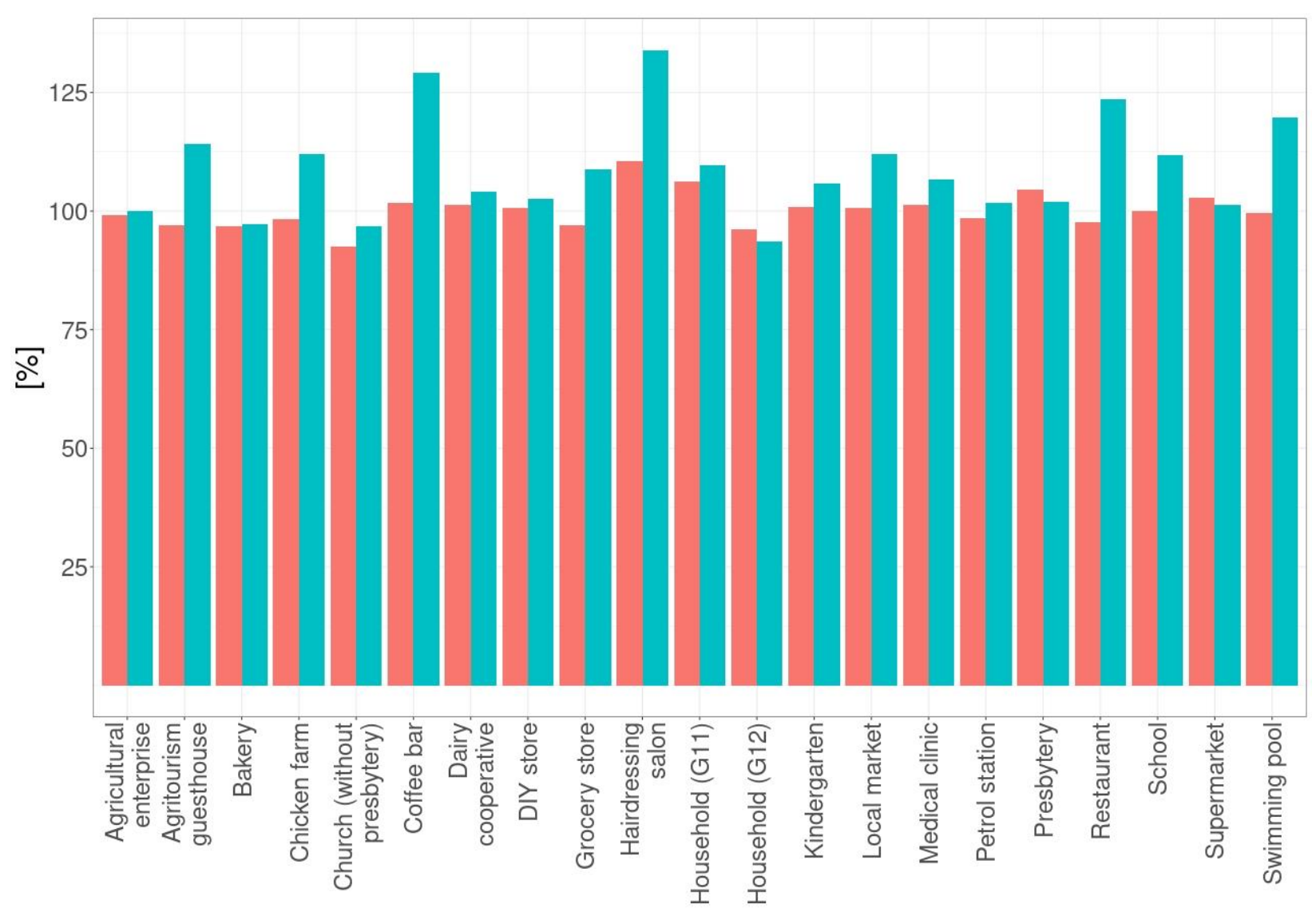

2019 relative to 2018 - 2020 relative to 2018

Figure 5. Dynamics of electricity exchange with the network broken down by prosumers and various analysis periods.

Figure 7 shows the dynamics of changes in the energy off-take from the network storage in the case_0 scenario. The results clearly indicate that for most prosumers, the possibility of acquiring energy accumulated in the virtual network storage significantly decreases. The lack of energy use caused by the decrease in its consumption translates into a loss for the prosumer. According to the applicable mechanism, counted from its introduction to the network storage, the energy unused within the annual billing period is lost. 


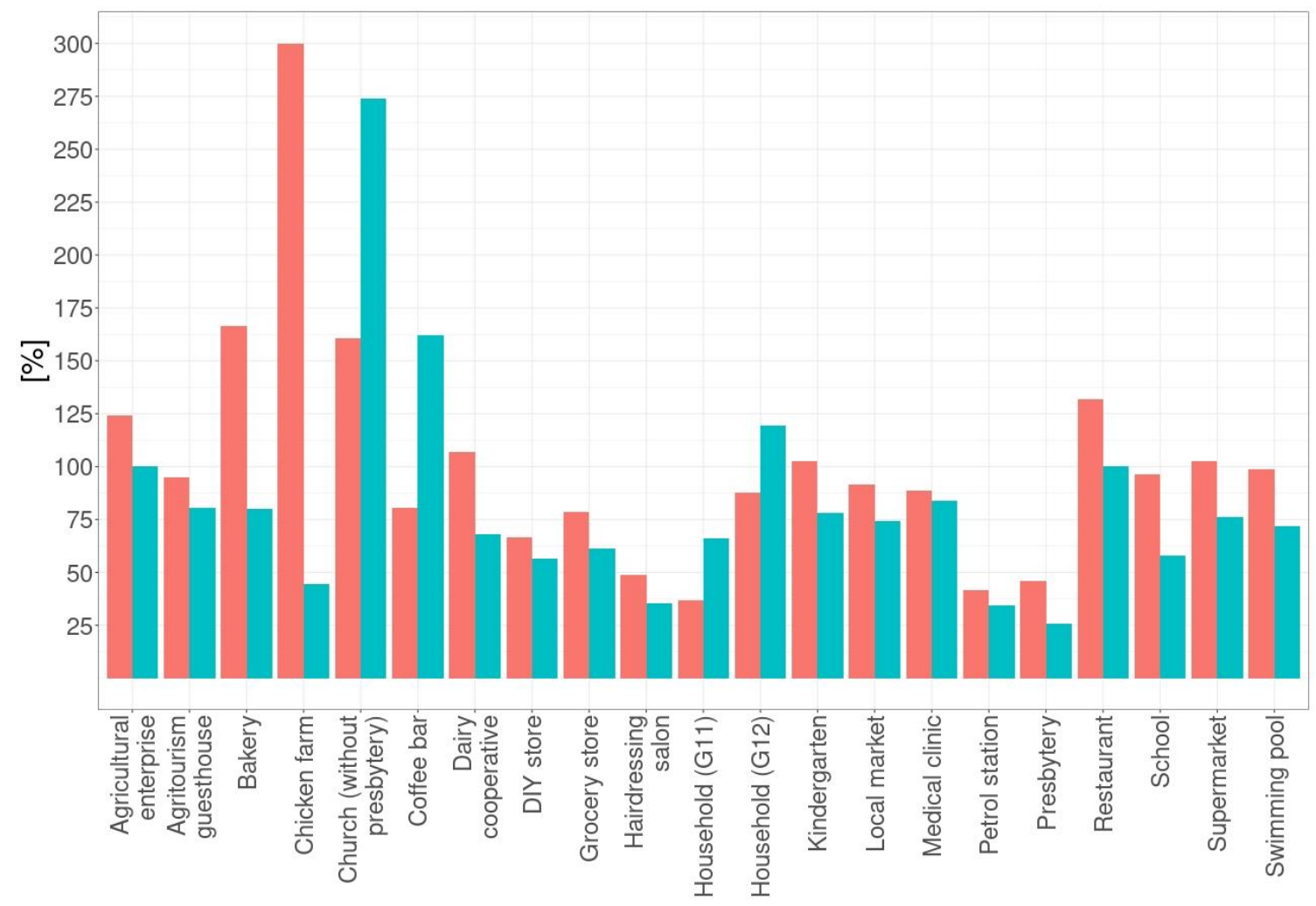

2019 relative to $2018 \quad 2020$ relative to 2018

Figure 6. Change in the electricity off-take/purchase from the network depending on the prosumer and year of analyses.

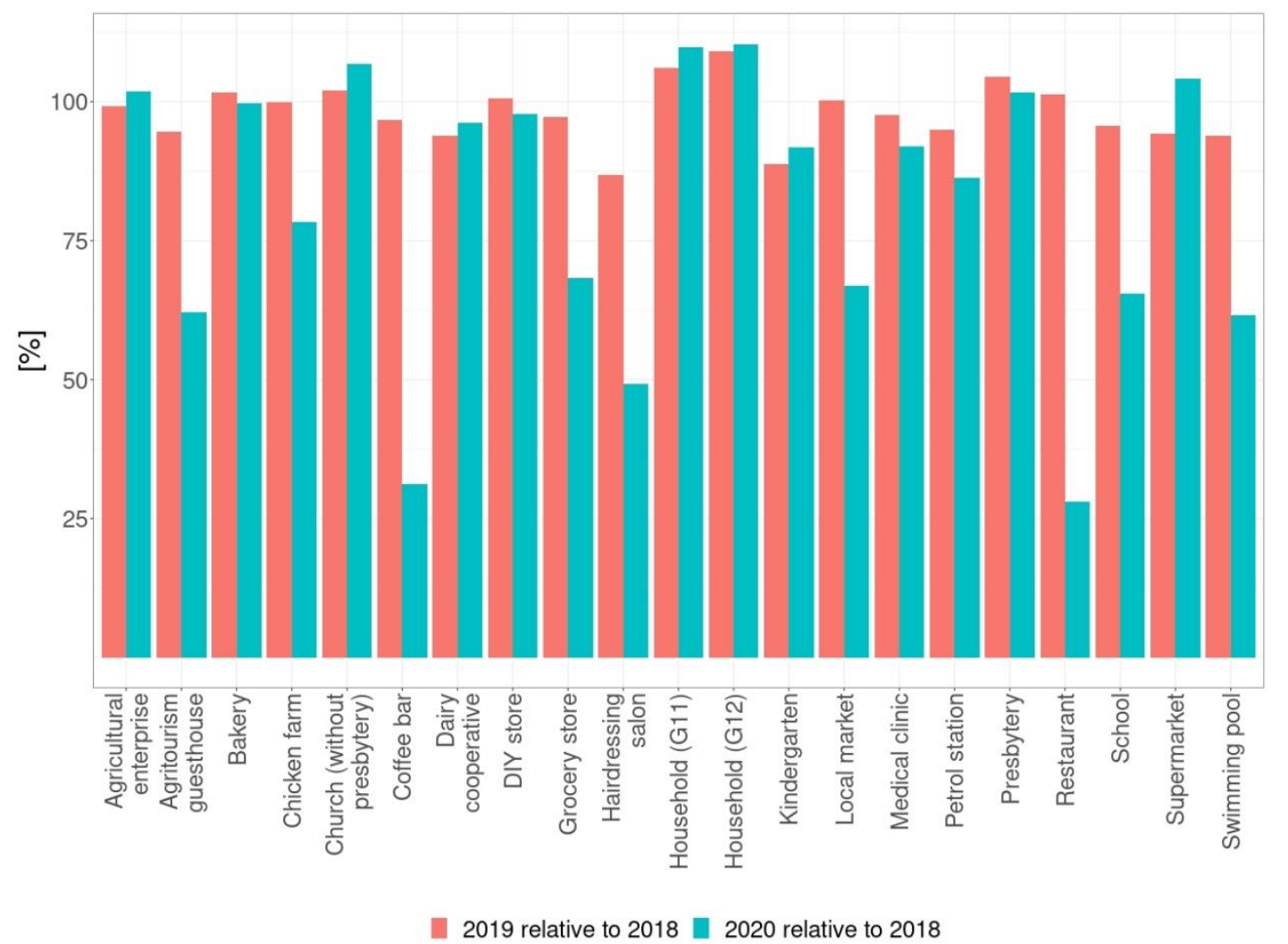

Figure 7. Change in electricity consumption from the network storage. 
It is worth emphasizing that the scale of the change seen, in particular for the service sector, part of which is for restaurants, the off-take from the storage is only approx. $28 \%$, and for coffee shops approx. 31\%.

- In Poland, the distribution and transmission network operators diagnosed a negative impact of prosumers using photovoltaic sources on the network's operation. The consequence of this diagnosis is the emergence of mechanisms alternative to the current prosumer support model and aimed at marketizing the functioning model. On the one hand, there is therefore mention of the high operating costs of the existing support model, which are cross-subsidized and transferred to consumers who are not prosumers, and, on the other hand, it is declared that the new model is to be more beneficial to prosumers. Is a win-win model possible? Figure 8 shows the energy purchase cost for each scenario averaged for the period from March 2018 to March 2021, and for all prosumers analyzed representing various industries in relation to the averaged energy purchase cost by consumers before they became prosumers. The most beneficial effect is the case_0 scenario, reflecting the currently applicable discount model. In this scenario, the average prosumer reduces the electricity purchase cost by $95.5 \%$ (only $4.5 \%$ of the original cost is left). The least beneficial scenarios include migration to the 1:1 discount model, where the prosumer incurs the full distribution cost for the energy taken (case_2) and the scenario of reselling surplus energy at the CRK and purchase of energy at tariff prices (case_1). For these variants, the average prosumer reduces the electricity purchase cost by $81.5 \%$, still incurring about $18.5 \%$ of the original level of energy purchase costs. Nor does the resale of energy at market prices improve the economic performance observed by the prosumer either in the case_3 or case_4 scenarios.

A slightly more precise inference can be made by analyzing each year separately, as presented in Figure 9.

For each year in the 2018-2020 period, the most beneficial results of minimizing the energy purchase costs were recorded for the existing discount scenario-case_0. It should be stressed that the reduction in the electricity consumption arising from restrictions in the operation of various sectors of the economy, resulting in its resale on the market, had a positive impact on cost reduction through revenue from resold energy. This is particularly visible for the case_1 scenario, where the share of the cost was reduced from $29 \%$ in 2018 to $8 \%$ in 2020. It should be noted that in principle the case_2 scenario, assuming that energy is stored in the network and taken without discount coefficients, generates a higher cost than the models assuming the resale of surplus on the market: case_1, case_3 and case_4. The lack of cost competitiveness in the case_1 scenario is caused by the need to pay distribution fees for all electricity taken from the network.

- The results obtained make it possible to assess the effectiveness of the proposed models of support for prosumers by referring to particular areas of the economy, as shown in Figure 10, and individual prosumers representing individual sectors of the economy, as shown in Figure 11. In each case, for the years when the energy consumption was stable and corresponded to the level for which the PV source power was selected, the most beneficial prosumer support scenario is the existing discount model-case_0.

However, other scenarios of marketization of mechanisms of support and resale of surplus electricity result in revenues that do not compensate for the electricity purchase costs when no energy is generated. An interesting situation occurs when there is a large surplus of energy that is not taken from the network in other periods. This may occur when a generation source is oversized, or when energy consumption is drastically reduced, for example, due to the COVID-19 pandemic. In this case, the prosumer will obtain the greatest benefits using mechanisms making it possible to resell the surplus energy, as shown in Figure 11, for prosumers such as: coffee shops, hairdressing salons, restaurants, swimming pools, small grocery shops, and agritourism guesthouses. 


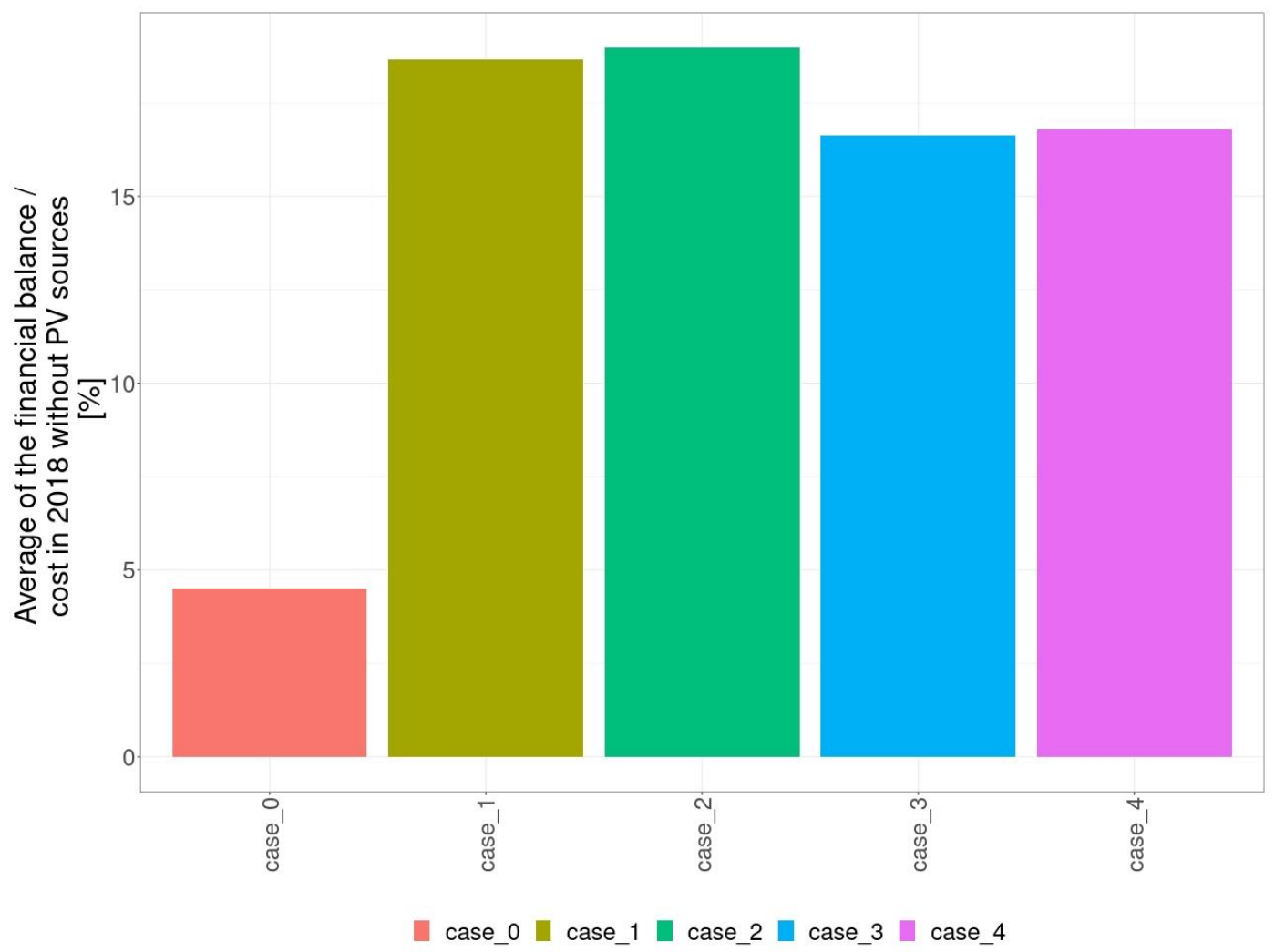

Figure 8. Share of the averaged balance of energy purchase costs for the whole analysis period and all prosumers in relation to the energy purchase costs in 2018 prior to obtaining the status of prosumers.

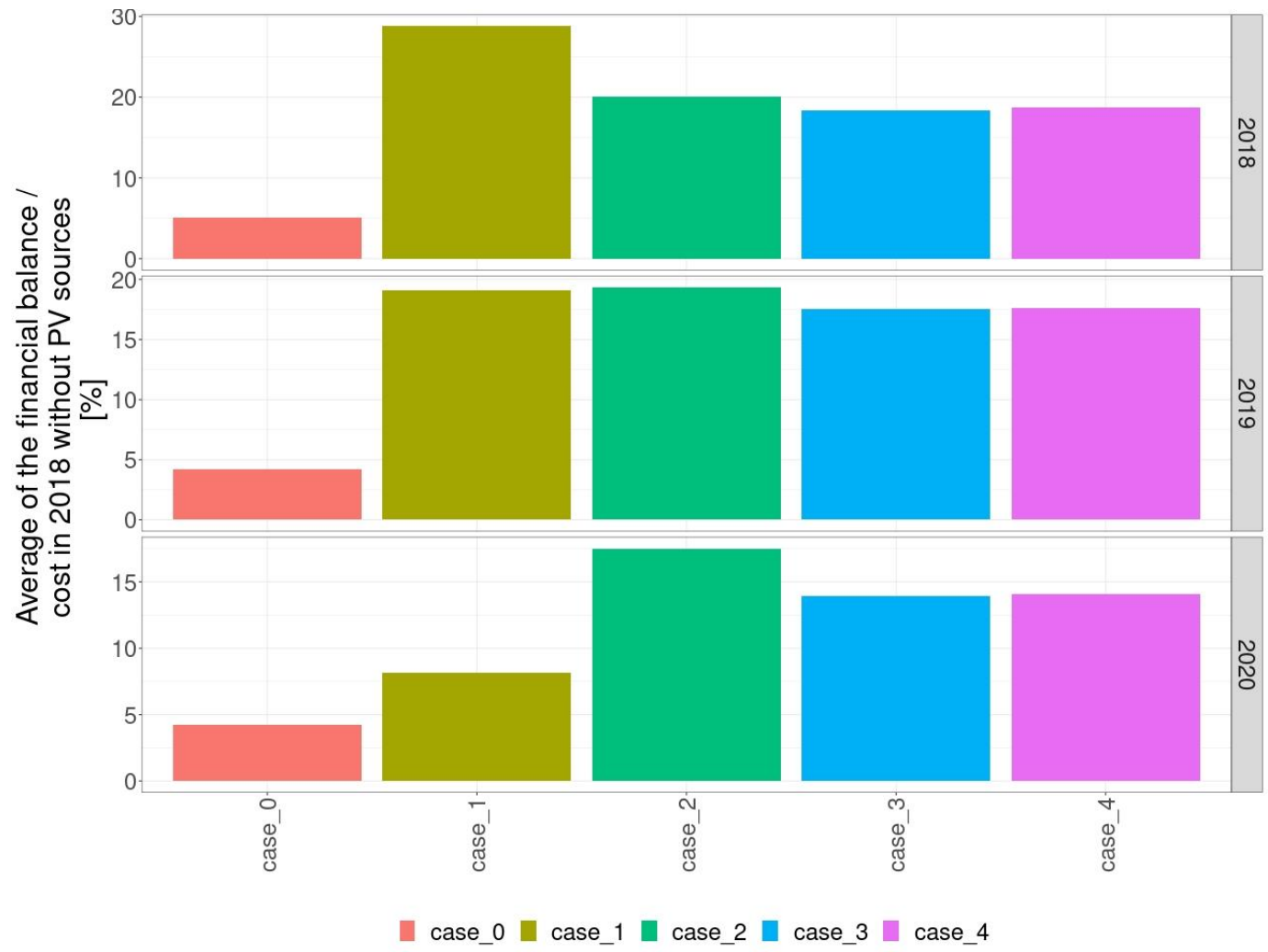

Figure 9. Share of the averaged balance of energy purchase costs for all prosumers for each year in the 2018-2020 period in relation to the energy purchase costs in 2018 prior to obtaining the status of prosumers. 


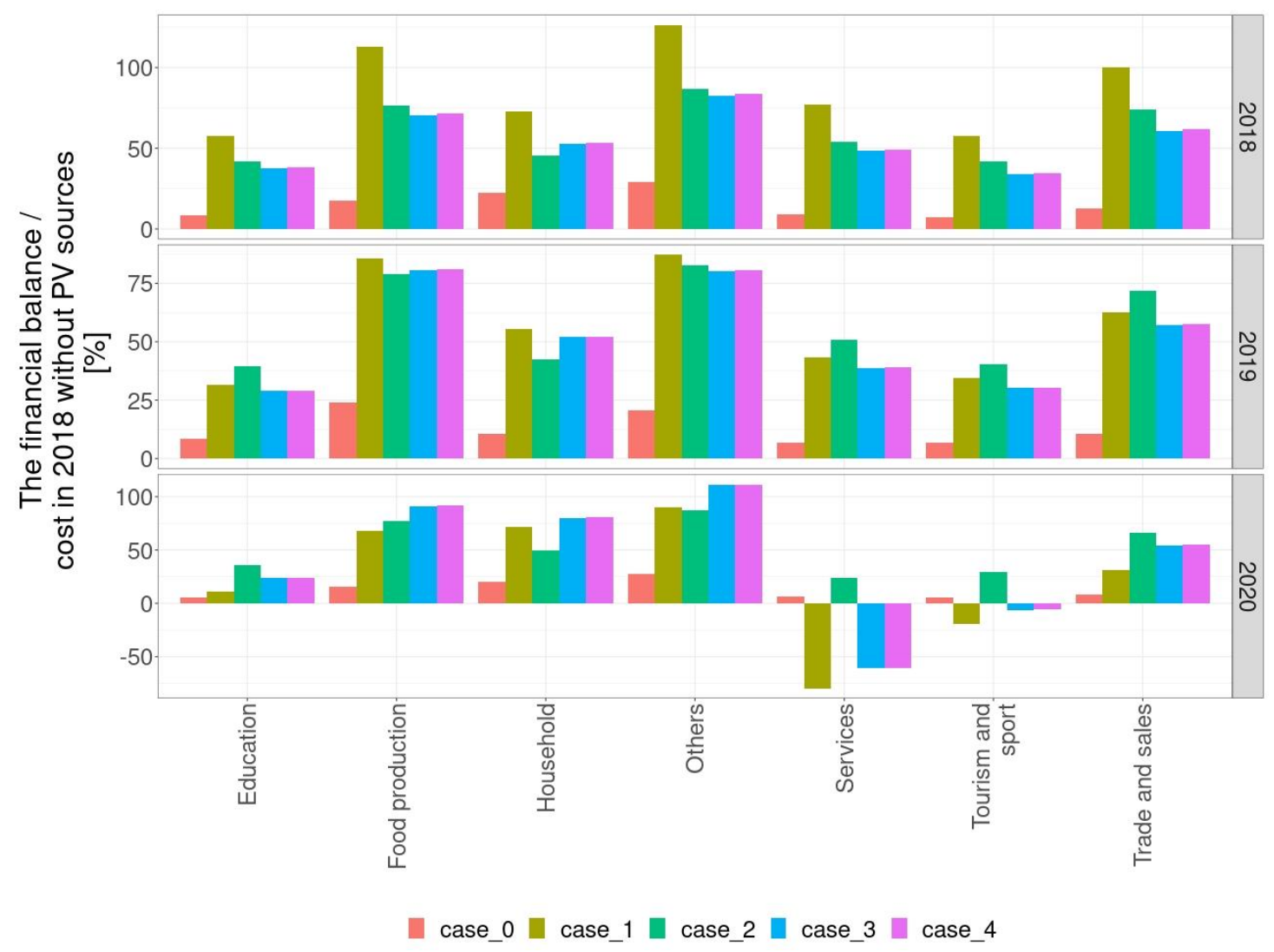

Figure 10. Share of the averaged balance of energy purchase costs for prosumers aggregated on the basis of economic activity for each year in the 2018-2020 period in relation to the energy purchase costs in 2018 prior to obtaining prosumer status.

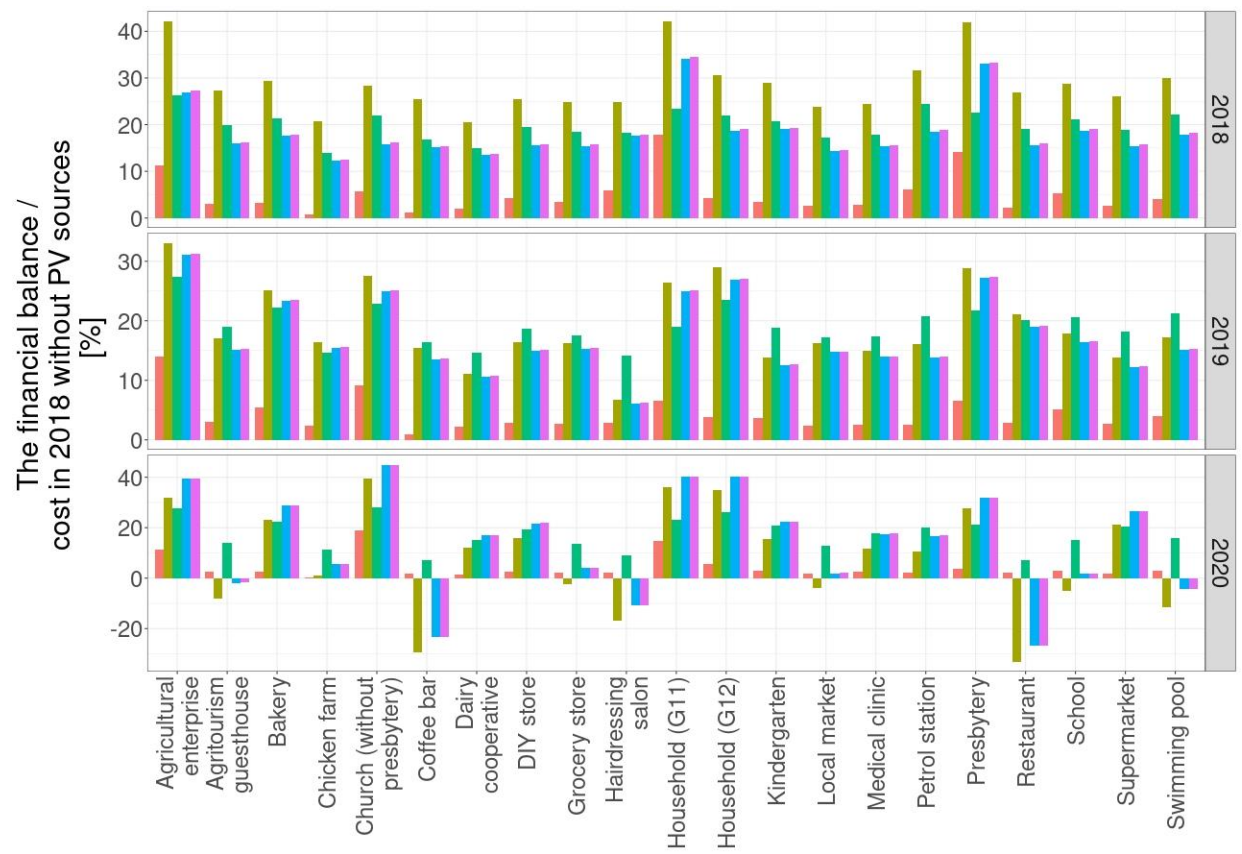

case_0 case_1 case_2 case_3 a case_4

Figure 11. Share of the averaged balance of energy purchase costs by individual prosumers for each year in the 2018-2020 period in relation to the energy purchase costs in 2018 prior to obtaining prosumer status. 


\section{Conclusions}

The objective of the study was to assess the impact of the proposed changes to the prosumer support mechanisms on the level of benefits obtained by prosumers, including the performance of sensitivity analyses reflected in different levels and stability of electricity consumption resulting from extreme situations caused by the COVID-19 pandemic.

- The basic conclusion to be drawn on the basis of the research is that the prosumer benefits most from participating in the currently applicable discount mechanism (case_0), in which the unused energy is fed into a network storage, from which $70 \%$ or $80 \%$ of the stored volume can be taken by the prosumer. These benefits result from the fact that the off-take of energy from the deposit is not subject to any fees. Possible costs occur only if the energy collected is in excess of that stored, which does not happen in practice with a well-selected generation source. This mechanism does not make it possible to resell surplus energy to the market and generate revenue, which seems to be consistent with the overarching objective of prosumerism, namely, building energy self-sufficiency, and not gaining profits from the sale of energy.

- At the level of the averaged financial effect for all prosumers, the analysis of the period from March 2018 to March 2021 makes it possible to conclude, that the least beneficial would be the implementation of the discount model (case_2) assuming the existence of a network storage allowing prosumers to deposit surplus energy and collect it in full, i.e., without discount coefficients. Unfortunately, any off-take of energy from the network is encumbered by a distribution cost, which translates into reduced benefits for the prosumer. For the case_2 scenario (similar for case_1) the average prosumer reduces the electricity purchase cost by $81.5 \%$, still incurring about $18.5 \%$ of the original level of energy purchase costs.

- Other mechanisms (case_1, case_3, case_4) allowing the prosumer to participate in the market and settle at market prices generate revenue that, however, in most cases do not cover the energy purchase costs in periods where no energy is generated. The financial effect and any potential benefit to the prosumer are strictly dependent on the market price levels and the volatility of energy demand. Therefore, in exceptional situations (COVID-19) — even for a well-designed capacity of a PV source guaranteeing energy self-sufficiency-there may be situations where profit is generated from the sale of energy on the market.

- In Poland, the COVID-19 pandemic has had a very significant impact on the level and profile of energy demand, which resulted from the government policy and introduction of limitations and restrictions on selected areas and sectors of the economy. This is particularly visible in the education, tourism and sport service sectors. It is worth emphasizing that in relation to the average demand from March 2018 to March 2020, demand in the pandemic period, i.e., March 2020-March 2021, decreased for the following types of business activities: (i) Trade and sales-15\%, (ii) Tourism and sport-39\%, (iii) Services-58\%, (iv) Education-19\%, (v) Food production-6\%, (VI) Others- $2 \%$. The only group that recorded an increase in the energy demand was Household- $5 \%$.

- The COVID-19 pandemic did not affect different sectors of the economy equally. The restrictions introduced by the government were both national and regional or localat the lower administrative levels (in voivodeships or poviats), restrictions generally applied only to selected industries. In the case of a full lockdown, some entrepreneurs repeatedly tried to act on the edge of the law, minimizing the effects of restrictions on their business. This resulted in a certain asymmetry in the economic impact of restrictions on entrepreneurs, which directly influenced their better or worse financial condition. Scaling this effect at national level, it had a different impact on the financial result of entire branches and sectors of the economy. Good examples are gyms and fitness centers, which were formally closed for a long time. However, there were no restrictions on training centers for sports competitions, which meant that many gyms 
and fitness clubs formally functioned as sports preparation centers, without changing their current business profile.

- Due to the scale and diversity of the problem, the results of analyses and research presented in the article treat the issues of the influence of COVID-19 on the development of the economy only in a fragmentary manner. In the opinion of the authors, it is worth continuing research in this area, in particular taking account of the sensitivity analyses and in the context of the impact of random global events on the network of sectoral connections, their interdependence and resistance to crises.

- Long-term or recurring economic and social restrictions related to COVID-19 resulted in difficulties in restoring the functioning of the economy and sparked a great deal of political controversy and social opposition. In the context of these experiences, it should be noted that during the fourth wave of the pandemic (which started in October 2021), the Polish authorities did not announce a nationwide lockdown and only intervened locally. Unlike this so far, this scenario of the government's actions implies an interesting field for the continuation of research and assessment of the impact of the COVID-19 on the functioning of economic sectors without introducing national restrictions. A comparative analysis of the state of different countries' economies with dissimilar approaches to restrictions might also be interesting.

Author Contributions: Conceptualization, J.J., M.K. and M.S.; methodology, M.S. and M.K.; formal analysis, J.J., M.K. and M.S.; investigation, M.K. and M.S.; resources, M.S.; writing-original draft preparation, J.J., M.K. and M.S.; writing-review and editing, J.J.; visualization, M.S. and M.K.; supervision, J.J. and M.S. All authors have read and agreed to the published version of the manuscript.

Funding: This research received no external funding.

Institutional Review Board Statement: Not applicable.

Informed Consent Statement: Not applicable.

Conflicts of Interest: The authors declare no conflict of interest.

\section{References}

1. Clean Energy for All Europeans Package. Available online: https://ec.europa.eu/energy/topics/energy-strategy/clean-energyall-europeans_en (accessed on 18 November 2020).

2. European Commission. Renewable Energy Progress Report; European Commission: Brussels, Belgium, 2020.

3. European Commission. A Clean Planet for All. A European Strategic Long-Term Vision for a Prosperous, Modern, Competitive and Climate Neutral Economy; European Commission: Brussels, Belgium, 2018.

4. European Parliament. Directive (EU) 2018/2001 of the European Parliament and of the Council of 11 December 2018 on the Promotion of the Use of Energy from Renewable Sources (Text with EEA Relevance); European Parliament: Strasbourg, Farance, 2018.

5. United Nations. Paris Agreement; United Nations: Paris, France, 2015.

6. Paska, J.; Surma, T.; Terlikowski, P.; Zagrajek, K. Electricity Generation from Renewable Energy Sources in Poland as a Part of Commitment to the Polish and EU Energy Policy. Energies 2020, 13, 4261. [CrossRef]

7. European Commission. The European Green Deal Communication from the Commission; European Commission: Brussels, Belgium, 2019.

8. Wójcik-Jurkiewicz, M.; Czarnecka, M.; Kinelski, G.; Sadowska, B.; Bilińska-Reformat, K. Determinants of Decarbonisation in the Transformation of the Energy Sector: The Case of Poland. Energies 2021, 14, 1217. [CrossRef]

9. Zamasz, K.; Stęchły, J.; Komorowska, A.; Kaszyński, P. The Impact of Fleet Electrification on Carbon Emissions: A Case Study from Poland. Energies 2021, 14, 6595. [CrossRef]

10. Brown, D.; Hall, S.; Davis, M.E. What is prosumerism for? Exploring the normative dimensions of decentralised energy transitions. Energy Res. Soc. Sci. 2020, 66, 101475. [CrossRef]

11. Ritzer, G.; Dean, P.; Jurgenson, N. The Coming of Age of the Prosumer. Am. Behav. Sci. 2012, 56, 379-398. [CrossRef]

12. Milčiuvienė, S.; Kiršienè, J.; Doheijo, E.; Urbonas, R.; Milčius, D. The Role of Renewable Energy Prosumers in Implementing Energy Justice Theory. Sustainability 2019, 11, 5286. [CrossRef]

13. Kaczmarzewski, S.; Olczak, P.; Sołtysik, M. The Impact of Electricity Consumption Profile in Underground Mines to Cooperate with RES. Energies 2021, 14, 5775. [CrossRef] 
14. European Economic and Social Committee Opinion: “Prosumer Energy and Prosumer Power Cooperatives: Opportunities and Challenges in the EU Countries" (Own-Initiative Opinion) 2017. pp. 44-52. Available online: https:/ / eur-lex.europa.eu/ legal-content/EN/TXT/?uri=uriserv\%3AOJ.C_.2017.034.01.0044.01.ENG\&toc=OJ\%3AC\%3A2017\%3A034\%3ATOC (accessed on 10 November 2021).

15. Mucha-Kuś, K.; Sołtysik, M.; Zamasz, K.; Szczepańska-Woszczyna, K. Coopetitive Nature of Energy Communities-The Energy Transition Context. Energies 2021, 14, 931. [CrossRef]

16. Czakon, W.; Mucha-Kuś, K.; Sołtysik, M. Coopetitive Platform: Common Benefits in Electricity and Gas Distribution. Energies 2021, 14, 7113. [CrossRef]

17. Cader, J.; Olczak, P.; Koneczna, R. Regional dependencies of interest in the "My Electricity" photovoltaic subsidy program in Poland. Polityka Energ.-Energy Policy J. 2021, 24, 97-116. [CrossRef]

18. Horstink, L.; Wittmayer, J.M.; Ng, K. Pluralising the European energy landscape: Collective renewable energy prosumers and the EU's clean energy vision. Energy Policy 2021, 153, 112262. [CrossRef]

19. European Commission. 2020 Report on the State of the Energy Union Pursuant to Regulation (EU) 2018/1999 on Governance of the Energy Union and Climate Action (Annex 2-Energy Subsidies in the EU); European Commission: Brussels, Belgium, 2020.

20. Alderete, M.V. The Age of Prosumerism: Some Micro-Economic Analysis. J. Theor. Appl. Electron. Commer. Res. 2017, 12, 1-12. [CrossRef]

21. RES LEGAL Europe-Renewable Energy Policy Database and Support (Information on the Main Support Schemes). Available online: http:/ / www.res-legal.eu/search-by-country/ (accessed on 11 October 2021).

22. Andrychowicz, M. RES and ES Integration in Combination with Distribution Grid Development Using MILP. Energies 2021, 14, 383. [CrossRef]

23. Andrychowicz, M. The Impact of Energy Storage along with the Allocation of RES on the Reduction of Energy Costs Using MILP. Energies 2021, 14, 3783. [CrossRef]

24. Seyfang, G.; Park, J.J.; Smith, A. A thousand flowers blooming? An examination of community energy in the UK. Energy Policy 2013, 61, 977-989. [CrossRef]

25. Palm, J.; Eidenskog, M.; Luthander, R. Sufficiency, change, and flexibility: Critically examining the energy consumption profiles of solar PV prosumers in Sweden. Energy Res. Soc. Sci. 2018, 39, 12-18. [CrossRef]

26. Yildiz, Ö. Financing renewable energy infrastructures via financial citizen participation-The case of Germany. Renew. Energy 2014, 68, 677-685. [CrossRef]

27. Zarębski, P.; Krupin, V.; Zwęglińska-Gałecka, D. Renewable Energy Generation Gaps in Poland: The Role of Regional Innovation Systems and Knowledge Transfer. Energies 2021, 14, 2935. [CrossRef]

28. Rokicki, T.; Bórawski, P.; Gradziuk, B.; Gradziuk, P.; Mrówczyńska-Kamińska, A.; Kozak, J.; Guzal-Dec, D.J.; Wojtczuk, K. Differentiation and Changes of Household Electricity Prices in EU Countries. Energies 2021, 14, 6894. [CrossRef]

29. European Commission. Commission Implementing Regulation (EU) 2020/1294 of 15 September 2020 on the Union Renewable Energy Financing Mechanism (Text with EEA Relevance); European Commission: Brussels, Belgium, 2020.

30. Brown, D.; Hall, S.; Davis, M.E. Prosumers in the post subsidy era: An exploration of new prosumer business models in the UK. Energy Policy 2019, 135, 110984. [CrossRef]

31. Ustawa z dnia 20 lutego 2015 r. o odnawialnych źródłach energii (Act of 20 February 2015 on Renewable Energy Sources) (Dz.U. 2020 poz. 261). Available online: http://isap.sejm.gov.pl/isap.nsf/DocDetails.xsp?id=WDU20200000261 (accessed on 11 November 2021).

32. Jasiński, J.; Kozakiewicz, M.; Sołtysik, M. Determinants of Energy Cooperatives' Development in Rural Areas-Evidence from Poland. Energies 2021, 14, 319. [CrossRef]

33. Jasiński, J.; Kozakiewicz, M.; Sołtysik, M. The Effectiveness of Energy Cooperatives Operating on the Capacity Market. Energies 2021, 14, 3226. [CrossRef]

34. Energy Regulatory Office Register of Obligated Sellers (Lista Sprzedawców Zobowiązanych). Available online: https: / / bip.ure.gov.pl/bip/rejestry-i-bazy/sprzedawcy-zobowiazani/3713,Lista-sprzedawcow-zobowiazanych.html (accessed on 10 November 2021).

35. Energy Regulatory Office-Tarrifs and Electricity Market Characteristics. Available online: https://www.ure.gov.pl/en (accessed on 11 November 2021).

36. PSE S.A.-The Polish Power System Market Energy Price-Rynkowa cena Energii Elektrycznej (RCE). Available online: https: / / www.pse.pl/dane-systemowe/funkcjonowanie-rb / raporty-dobowe-z-funkcjonowania-rb/podstawowe-wskaznikicenowe-i-kosztowe/rynkowa-cena-energii-elektrycznej-rce (accessed on 11 November 2021).

37. TGE Day-Ahead Market and Intra-Day Market SIDC (XBID)—Spot Market for Electricity in Poland. Available online: https: //tge.pl/electricity-dam (accessed on 11 November 2021).

38. Energy Regulatory Office Average Selling Price of Electricity on the Competitive Market (Annual and Quarterly)Średnia cena Sprzedaży Energii Elektrycznej na Rynku Konkurencyjnym (Roczna i Kwartalne). Available online: https://www.ure.gov.pl/pl/energia-elektryczna/ceny-wskazniki/7852,Srednia-cena-sprzedazy-energii-elektrycznej-narynku-konkurencyjnym-roczna-i-kwa.html (accessed on 11 November 2021).

39. Energy Regulatory Office Electricity Tariffs-Taryfy Energii Elektrycznej. Available online: https://bip.ure.gov.pl/bip/taryfy-iinne-decyzje-b/energia-elektryczna (accessed on 11 November 2021). 
40. Kaczmarek, T. Administrative division of Poland-25 years of experience during the systemic transformation. EchoGéo 2016, 35 . [CrossRef]

41. Rataj, M.; Berniak-Woźny, J.; Plebańska, M. Poland as the EU Leader in Terms of Photovoltaic Market Growth Dynamics-Behind the Scenes. Energies 2021, 14, 6987. [CrossRef]

42. Zakeri, B.; Gissey, G.C.; Dodds, P.E.; Subkhankulova, D. Centralized vs. distributed energy storage-Benefits for residential users. Energy 2021, 236, 121443. [CrossRef]

43. The Comprehensive R Archive Network. Available online: https:/ / cran.r-project.org/ (accessed on 30 October 2021).

44. Bivand, R.S.; Pebesma, E.J.; Gómez-Rubio, V. Applied Spatial Data Analysis With R, 2nd ed.; Use R! Springer: New York, NY, USA, 2013; ISBN 978-1-4614-7618-4.

45. Heumann, C.; Schomaker, M.; Shalabh. Introduction to Statistics and Data Analysis: With Exercises, Solutions and Applications in R, 1st ed.; Springer International Publishing: Cham, Germany, 2016; ISBN 978-3-319-46162-5.

46. López-Sosa, L.B.; Alvarado-Flores, J.J.; del Niño Jesús Marín-Aguilar, T.; Corral-Huacuz, J.C.; Aguilera-Mandujano, A.; RodríguezTorres, G.M.; Morales-Máximo, M.; del Carmen Rodríguez-Magallón, M.; Alcaraz-Vera, J.V.; Ávalos-Rodríguez, M.L.; et al. COVID-19 Pandemic Effect on Energy Consumption in State Universities: Michoacan, Mexico Case Study. Energies 2021, 14, 7642. [CrossRef]

47. Malec, M.; Kinelski, G.; Czarnecka, M. The Impact of COVID-19 on Electricity Demand Profiles: A Case Study of Selected Business Clients in Poland. Energies 2021, 14, 5332. [CrossRef]

48. Christopoulos, A.G.; Kalantonis, P.; Katsampoxakis, I.; Vergos, K. COVID-19 and the Energy Price Volatility. Energies 2021, 14, 6496. [CrossRef]

49. Oviedo-Gómez, A.; Londoño-Hernández, S.M.; Manotas-Duque, D.F. Effects of the COVID-19 Pandemic on the Spot Price of Colombian Electricity. Energies 2021, 14, 6989. [CrossRef] 